\title{
Ways to deal with the 'temporary' value of cost benefit analysis
}

\author{
J. M. Vleugel ${ }^{1} \&$ E. J. Bos ${ }^{2}$ \\ ${ }^{I}$ OTB Research Institute, TU Delft, The Netherlands \\ ${ }^{2}$ LEI, The Netherlands
}

\begin{abstract}
A key problem with social cost benefit analysis (CBA) is that ex ante and ex post analyses of the same (infrastructure) project in many cases have different outcomes. Ex ante analyses are used to decide whether new infrastructure has sufficient net benefits for society, provided that a set of assumptions has been met. If this is the case, and sufficient budget is available, it is likely that a project to build this infrastructure is initiated. Ex post analyses are used to evaluate the real impact of the new infrastructure. This divergence between mentioned outcomes may lead to serious debates in politics and society, especially in cases where the ex post impact of a project is much lower than the ex ante calculations predicted. This is frequently the case for railway projects. In this paper we deal with this issue by discussing the main causes of this divergence and suggest some practical solutions. The main conclusion is that the way infrastructure projects are planned and developed may need reconsideration, looking at, in particular, environmental effects. This paper is based on ongoing studies.
\end{abstract}

Keywords: cost benefit analysis, environment, transport, decision-making.

\section{Introduction}

Cost-benefit analysis (CBA) "is a practical and rigorous means of identifying, targeting and checking the impacts of regulatory measures on the underlying causes of the ills with which regulators need to deal, those causes being the market failures that in turn may justify regulatory intervention" [1].

Intervention in this paper is restricted to public investments in infrastructure. Infrastructure is in most cases supplied as a public good, although it can also be supplied by private companies (in case of toll roads or privatized railway lines). 
CBA is a "tool to improve policy making, not an instrument to set policy goals or to determine which options decision makers should consider" [2]. The output of a CBA is the following: main problem, key assumptions, main option(s) considered, an appraisal to quantify the costs and benefits of these options, and if necessary involved trade-offs [3].

In the Netherlands, CBA is the main tool to support decision-making regarding public investments in infrastructure. In case of large investments, public bodies are by law obliged to commission a CBA. This means that the quality of $\mathrm{CBA}$ is of vital importance for decision-making regarding such projects. CBA is employed ex ante, which means that it is carried out before the construction of the infrastructure starts, hence also well in advance of the actual use of the infrastructure.

If a CBA would be carried out after the project is finished or when the infrastructure is already in use, this so-called ex post CBA may have a (significantly) different outcome.

In this paper, we will first elaborate a set of reasons why ex ante and ex post CBA may have different outcomes (see Section 2). This overview will then be applied to a real infrastructure case - the Betuwe dedicated freight railway line connecting Rotterdam port with its European hinterland (see Section 3).

Section 4 is devoted to the impact of project changes on investment cost, including those associated with the environment. Finally, Section 5 contains conclusions and recommendations.

\section{The difference between ex ante and ex post CBA}

\subsection{Introduction}

A CBA measures the welfare change due to the implementation of a project (plan scenario), in reference to the situation that the project would not have been implemented (autonomous development). In case of an ex ante CBA, the purpose of CBA is to support decision makers in making a choice between (variants of) a plan based on calculated impacts. Subsequently, effects have to be identified, quantified and expressed in economic terms. In case of an ex post CBA, the real impact of the (variant of a) plan that was realized is analyzed and only the autonomous development has to be assessed afterwards ('what would have happened if not').

Comparing ex ante and ex post is not common practice, given the different purposes of CBA in each case. However, it is common practice in politics and society to look back and question or even criticize past investment decisions in terms like '(in) adequate', '(un) sufficient', etc. This makes it in our opinion inevitable for science to elaborate this matter as well. Others are of the same opinion [4]: "Although we do not believe that the primary purpose of ex post $\mathrm{CBA}$ is to test ex ante estimates, we recognize that the results of ex post and ex ante CBA will inevitably be compared (if, as we assume, the results of ex post CBA are published). Such comparisons may have some value in helping to improve future ex ante analysis. It is therefore important to understand why differences between ex ante estimates and ex post figures might arise." 


\subsection{Towards an explanation of the differences: theory}

Ex ante CBA is based on a set of assumptions regarding the future in which the foreseen infrastructure is being used. The amount of use of the infrastructure is one of the determinants of the long-term socio-economic impact of the infrastructure.

When developing infrastructure a key issue is to make a reasonable prediction about future demand for services using the new infrastructure. Many determinants play a role here, and the analyst has to make assumptions about each of them, and at least as important, about the interaction of these factors, because some factors are likely to stimulate demand, while others may work in the opposite direction.

Infrastructure has a considerable lifespan in which the factors influencing future use of the infrastructure may change significantly. For instance, traditionally main customers of freight railways were manufacturers of high mass goods. These goods, such as liquid bulk (e.g. fuels) and fixed bulk (e.g., steel pipes) are transported in high volumes. If an economy transitions towards a so-called post-fordian state, in which services become the dominant economic sector, then the demands on transport of manufactured goods may become much different. In such a society large-scale production is to a large extent replaced by smaller-scale tailor-made production. Finished goods are imported instead of being manufactured in the country or region. Goods are shipped in smaller batch sizes with a much higher delivery frequency. Stocking parts and goods is regarded as non-productive investment, hence reduced as much as possible. Society becomes dependent on reliable - just-in-time - transport services. Delivery by lorries is then the most practical transport solution, despite the fact that roads become increasingly congested and building new roads has become increasingly difficult, at least in the Western world. For other products, new opportunities for railways appear, like overland transport of (sea) containers with consumer products. Many of them are transported by road, but rail may be able to get a fair share, witness the frequent use of container trains.

Such transitions in the economy are an example of trends in the determining factors of transport, which cannot be easily be predicted for a longer period of time. All these development influence the demand for infrastructure and thus its benefits. Obviously, when practice differs from what was predicted, the ex post CBA outcome deviates from the ex ante CBA assessment.

Also concerning costs, ex ante assessments and ex post outcomes may diverge. Several factors may influence the uncertainty of ex ante assessment of investment cost. If a good is very specific the uncertainty of cost assessments increases. For example, a special type of bridge is likely to cost more than a standard type, but how much more is only known when it is finished. Experience with developing a product or service is another factor that has an impact on the (un) certainty of assessments. Lack of experience increases the uncertainty of assessments. This especially holds for assessment of the environmental impact of infrastructure.

Much of the biases concerning costs and benefits relate to the fact that information was not available on the time of the ex ante evaluation. However, it 
can also not be excluded that costs were mitigated in order to secure a favourite decision towards the project. Hiding information during ex ante assessment is known as client friendly consultancy.

\section{The Betuwe freight railway line}

\subsection{Railways in transition}

Rail freight transport has been declining for decades in Europe due to changes in energy supply (gas, oil and nuclear energy replacing coal), manufacturing and consumption. Financial deficits of the usually state-owned railway companies rose to an unbearable level and restructuring became inevitable. The role of the state with respect to (freight) railways changed. The European Union started a railway reform policy intended to create a competitive railway market. National governments split railway companies in infrastructure providers and service companies. Funding of the railway infrastructure remained a public activity in most countries, because private companies were unwilling to accept political risks (of changing or canceling railway projects) and had a relatively short time horizon with respect to the payback period of investments.

Two few major railway projects were initiated in the nineteen nineties in the Netherlands: the high-speed passenger railway line connecting Amsterdam, Rotterdam, Antwerp, Brussels and Paris, and the Betuwe dedicated rail freight line. The latter project will be discussed in this paper.

\subsection{The Betuwe railway project}

This project was initiated in a period in which several important issues emerged on the agenda of policy-makers in the Netherlands.

A first issue was the reinvention of the classical idea of international division of labour by authors like Michael Porter [5]. Following their ideas, every country should concentrate on specific competitive advantages. For centuries, The Netherlands is a major trading country. A specialization in transport and logistics follows from this. The national government translated Porters' ideas into a socalled mainport strategy, which concentrated on the development of the main transport networks and nodes, like harbours (Rotterdam, Amsterdam) and airports (Schiphol). Certain transport axes were regarded as main links to connect the countries main ports with the hinterland (Germany and other countries in Europe). Germany is the main importer of goods transported on Dutch roads, rail and inland waterways (by barges).

Among these main axes was a new, dedicated railway line for freight, connecting Rotterdam harbour with its German hinterland; the Betuwe rail freight line. In the same period (1980s-1990s), environmental and liveability issues were put on the agenda of politicians. The railway line enables rail freight operators to reroute a major share of rail traffic from the existing main east-west corridor, which crossed important urban areas, to this new railway line. The environmental and liveability impact of rail transport is regarded as lower, while 
traffic safety is higher than road transport. Then there was growing congestion on the rail network, leading to conflicts in scheduling passenger and freight trains. Growing congestion on the road network, and the peculiarities of barge transport (inland waterways do not cover the whole of Europe and use is depending on waterway conditions) did their share to stimulate the national government to develop this new railway line. The idea to develop this infrastructure came in 1989, while the infrastructure was put in operation in 2007 [6].

The project consists of $160 \mathrm{kms}$ double track without level crossings. The line is electrified with $25 \mathrm{kV}$ and equipped with the ERTMS safety system. To protect the environment and liveability the following was built: 160 fauna tunnels, 5 railway tunnels and bundling with the existing A15 main road. The infrastructure should last for some 100 years [7].

Regular traffic is growing, despite some technical issues related to signaling and safety of tunnels.

Figure 1 shows the line between the North Sea (Noordzee) and Germany (Duitsland).

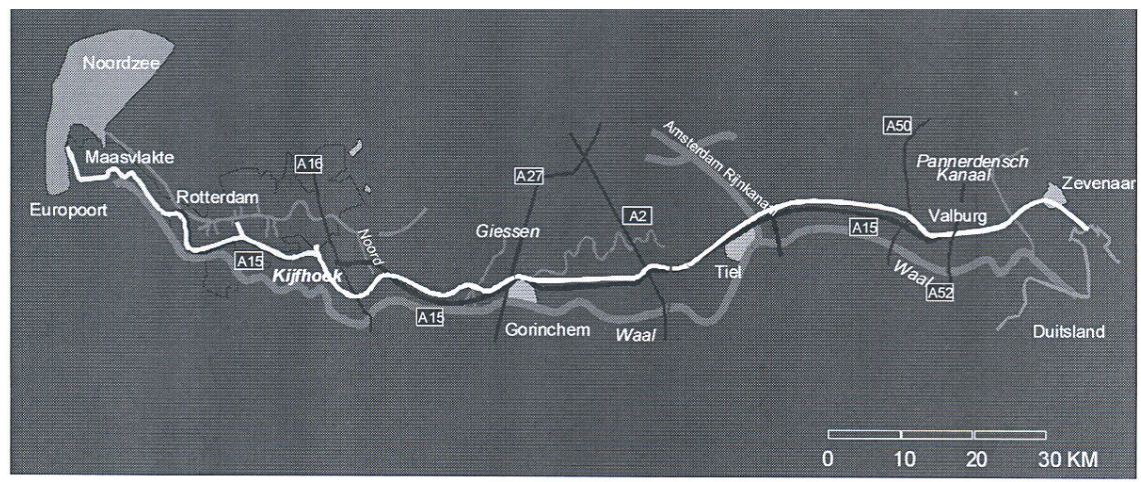

Figure 1: The Betuwe freight line. Source: [8].

Many studies have been carried out into the costs and benefits of this railway line, with results leading to positive and negative advice for the government. We will not discuss these studies in detail, but concentrate on some major uncertainties.

\subsection{Uncertain benefits and costs}

\subsubsection{Benefits}

A major uncertainty is related with forecasting demand. After decades of decline a trend change became visible in some countries in the 1990s. In the Netherlands the volume of international freight by rail has risen from 20 million tons in 1995 to 41 million tons in 2005 due to economic growth, internationalization of good production and consumption (globalization) and closure of German coalmines. 
Second, institutional reform led to more between rail operators, offering more diversified, lower cost services [9]. Transport growth was concentrated mainly in containers, coal, other minerals, cars and steel.

The latest prognoses [9] for the year 2020 range from 34 to 91 million tons (or 75.000 to 140.000 freight trains) per year. This wide range indicates that the impact of the demand determining factors on demand may vary substantially over time.

Actual use affects the income of the rail operators and (via the user charges paid) also of the railway line owner.

\subsubsection{Costs}

Relevant costs can be divided into two main groups: pure infrastructure costs and costs made in order to protect the environment and liveability.

Uncertainties with respect to project costs may come in several ways. First, there may be technical changes to the project, for instance, the line may be extended; this is called a change of the scope of the project. Second, some disruptions may occur during building, like unknown or unstudied geological conditions, which may impact the routing of the project and building time. Third, resistance from local citizens or environmental groups (known as Not in my backyard or Nimby response) may force developers to change their plans. They have to invest in mitigating measures, such as building noise shields or tunnels or even rerouting (part of) the line in order to reduce the adverse impact on the environment. To some extent this is also a change of scope of the project.

Some of these changes and adaptations may be predictable, but not all of them. Their impact can even vary per case, which means that past projects, if at all similar are no direct basis for comparison.

Such changes are likely to increase the costs of an infrastructure project.

\subsection{Reconsider or reject the project?}

In case of a (much) lower demand than forecasted, two things are important. First, if the benefits are so low that they may not cover the costs of the project, a negative cost-benefit ratio will result. Second, the payback period of the investment becomes much longer or even infinite. Hence, both a social costbenefit analysis as well as a private investment analysis would probably lead to at least a reconsideration or even rejection of the project.

Given the size of this paper, the paper concentrates on the costs of this project.

\section{Impact of project changes on investment costs}

\subsection{Introduction}

The impact of (1) technically and (2) socially induced changes on the Betuwe rail freight line was substantial. Table 1 shows what happened between the first cost estimates and the (nearly) finalization of the project. 
Table 1: Development of costs for the Betuwe rail freight line (in mln. Euros).

\begin{tabular}{|c|c|c|}
\hline Date/period & Extra & Total \\
\hline $\begin{array}{l}\text { 1. June 1990: Cost estimate with } 50 \% \text { private } \\
\text { financing }\end{array}$ & & 1.134 \\
\hline $\begin{array}{l}\text { 2. January 1992: Extension to Rotterdam-harbour } \\
\text { (Maasvlakte) }\end{array}$ & +363 & 1.497 \\
\hline $\begin{array}{l}\text { 3. April 1992: Choice of trajectory Maasvlakte- } \\
\text { Zevenaar }\end{array}$ & +838 & 2.335 \\
\hline $\begin{array}{l}\text { 4. May 1993: Adaptations to mitigate adverse } \\
\text { effects on the environment (local resistance) }\end{array}$ & +497 & 2.832 \\
\hline 5. September 1993: Mark-up for price inflation & +72 & 2.904 \\
\hline $\begin{array}{l}\text { 6. December 1993: Adaptation to parliamentary } \\
\text { and provincial demands, Barendrecht now in the } \\
\text { project }\end{array}$ & +335 & 3.239 \\
\hline 7. September 1994: Mark-up for price inflation & +119 & 3.358 \\
\hline $\begin{array}{l}\text { 8. Budget Tracébesluit (trajectory decision) 1996; } \\
\text { adaptations including } 4 \text { new tunnels }\end{array}$ & +386 & 3.744 \\
\hline $\begin{array}{l}\text { 9. Change of scope due to political decisions (e.g., } \\
\text { Dintelhaven bridge, double-stack ready tunnels } \\
\text { etc.) }\end{array}$ & +321 & 4.065 \\
\hline 10. 1996-2005: Mark-up for price inflation & +783 & 4.848 \\
\hline 11. Prognosis 1-1-2006 including risks & +3.714 & 4.653 \\
\hline $\begin{array}{l}\text { 12. Balance of higher and lower costs } \\
\text { (temporarily) }\end{array}$ & & -195 \\
\hline
\end{tabular}

Note: All cost exclusive VAT.

Source: [10].

\subsection{The differences between ex ante and ex post CBA}

Following Table 1, four main sources of differences can be distinguished:

a) Change of the plan scenario (Table 1, points 2, 3, 8, 9): $1.908 \mathrm{mln}$. Euros. 
This is a political decision.

b) Costs to mitigate the impact of the infrastructure on the environment. (Table 1, point 4): $497 \mathrm{mln}$. Euros. This is an (non consumer preference based) assessment of society's WTP to prevent adverse effects on nature.

c) Inflation (Table 1, point 5, 7, 10): $974 \mathrm{mln}$. Euros.

d) Project risk (Table 1, point 11): either budgeted, unspecified or 'hidden'.

The latest cost prognosis [11] mentions a sum about $4.700 \mathrm{mln}$. Euros, which actually implies a quadrupling of project costs.

What remains hidden in this official calculation is the impact of assessment bias, as discussed earlier. We may refer to an earlier paper [12].

\subsection{Decision making}

Political decision making is a complex process in which financial-economic, socio-economic and also political-strategic considerations play a key role.

Many major investment projects are carried out because politicians like to make statements. In order to safeguard a project, there is an inherent bias to overestimate the net benefits of a project and to underestimate its costs. If a project has a not so beneficial or even negative outcome, CBA is treated as one of the inputs of the process of decision making, but not the dominant one [13]. It may then be a task for economists to reduce this 'abuse' of CBA, e.g. by defining strict guidelines for CBA.

Once a plan to build new infrastructure is presented, and especially in case of so-called 'grand projects', like a railway line cutting through a country from east to west, it becomes apparent that not everyone is in favour of the project. In case of this project a vivid discussion started between national decision makers on one side and local and provincial stakeholders on the other side. Especially in the province of Gelderland there was a lot of resistance, because of the negative impact of the railway line on the landscape and liveability, the opinion that (their) inland waterways could accept the additional traffic without any problem and the (perceived) lack of local and regional-economic benefits.

The national government continued its support for the project nonetheless. In order to overcome this resistance major mitigation works were carried out (as mentioned in Table 1, point 4).

The cost of measures to mitigate adverse effects on the environment can be regarded as an indication of the social willingness to pay to prevent (more) damage to the environment. In case of the Betuwe rail freight line, this social willingness to pay equals almost half a billion Euro.

\subsection{CBA and planning; some considerations}

This project was not only confronted with strong opposition, but also a lobby started to stop it. But, the procedure to develop the project continued.

What, however, if the project would have been stopped at some moment? What would have been the economic impact of such a decision or the impact on liveability and the environment? Such questions have not been answered in a quantitative way. Nonetheless, they are very relevant. To use CBA in such a 
context may lead to adaptations in the way CBA is usually carried out. Table 2 gives examples of two CBAs carried out at different moments in time.

Table 2: $\quad$ Multi-step CBA.

\begin{tabular}{|l|l|l|l|l|}
\hline & $\begin{array}{l}\mathrm{CBA}_{1} \text { net } \\
\text { value }\end{array}$ & Decision & $\begin{array}{l}\mathrm{CBA}_{2} \text { net } \\
\text { value }\end{array}$ & Decision \\
\hline Project 1 & $<0$ & No go & & \\
\hline Project 2 & $>0$ & Go & $<0$ & Adapt or stop \\
\hline Project 3 & $>0$ & Go & $>0$ & $\begin{array}{l}\text { Continue (limited } \\
\text { adaptation) }\end{array}$ \\
\hline
\end{tabular}

In order to successfully apply such a step-wise framework, the project considered should have particular characteristics, more in particular, it should be changeable or split into separate stages, which are not linked in a technical sense (lack of indivisibilities).

\section{Conclusions and recommendations}

In this paper we compared ex ante and ex post CBA. Although such a comparison may be criticized given the different reasons for carrying out ex ante and ex post CBA, in practice it clearly makes sense.

The sources for deviations have been analyzed and quantified in economic terms for the Betuwe rail freight line case study. Four main sources are important: i) changes to the plan scenario, ii) (unforeseen) costs to mitigate the impact on the environment, iii) inflation and iv) project risk. From the referred case study it also follows that the willingness to pay for mitigating adverse environmental effects is 500 million Euros. This indicates that both Dutch policy makers and citizens consider the environmental impact of infrastructure a serious issue. As such they have a clear role in future CBAs for infrastructure in the Netherlands.

It may be a good idea to plan a project in a way that enables decision makers to later correct (presumably) 'wrong' decisions. CBA could then be carried out repeatedly and become a more dynamic tool to support decision-making.

Next to delivering financial benefits for society this approach may also be quite beneficial for the environment.

\section{References}

[1] Financial Services Authority (FAS), Practical Cost-Benefit Analysis for Financial Regulators Version 1.1, London, p. 5, 2000.

[2] Ibid, p. 1.

[3] Ibid, p. 19. 
[4] NERA Economic Consulting, The FSA's Methodology for Cost-Benefit Analysis, London, pp. 26-27, 2004.

[5] Porter, M., The Competitive Advantage of Nations, Free Press, 1990.

[6] Ministerie van Verkeer en Waterstaat, Betuweroute, Voortgangsrapportage 22, Den Haag, 2007.

[7] See footnote 6 .

[8] Keyrail, information provided, 2008.

[9] Francke, J., Oostroom, H. van, and Savelberg, F., Marktontwikkelingen in het goederenvervoer per spoor 1995-2020, Kennisinstituut voor Mobiliteitsbeleid, Den Haag, pp. 65-66, 2007.

[10] Prorail, De Betuweroute, slagader van het goederentransport per trein, Utrecht, 2007.

[11] See footnote 6.

[12] Vleugel, J.M. \& Bos, E.J., Enige kanttekeningen bij kosten-baten analyse, paper presented at Colloquium Vervoersplanologisch Speurwerk 2007, 22 and 23 November 2007, Antwerp.

[13] TCI, Tijdelijke Commissie voor de Infrastructuur. Onderzoek naar infrastructuurprojecten. Reconstructie HSL-Zuid: de besluitvorming uitvergroot, Tweede Kamer, vergaderjaar 2004-2005, 29283, nr. 8, SDU, Den Haag, 2004. 